\title{
Is instant porridge with a high calcium content based on Moringa oleifera as an alternative baby food to prevent stunting in Indonesia?
}

\author{
Septa Katmawanti, ${ }^{1}$ Supriyadi, ${ }^{2}$ Fariha Mariroh $^{3}$ \\ ${ }^{1}$ Department of Public Health, Faculty of Sport Science, Universitas Negeri, Malang; ${ }^{2}$ Department of Sport \\ Science, Faculty of Sport Science, Universitas Negeri, Malang; ${ }^{3}$ Departement of Public Health, Public Health \\ Faculty, Universitas Negeri, Jember, Indonesia
}

\begin{abstract}
Background: According to WHO, stunting is a state of heightfor-age index below minus two standard deviation. However, the condition could be prevented by giving suitable complementary food to babies and toddlers. Moringa leaves are rich in vitamins A, $\mathrm{C}, \mathrm{B} 6$, as well as calcium, potassium, iron, as well as protein, and are therefore used as complementary foods for breast milk, in baby feeding.

Design and Methods: Instant porridge was developed using three formulas. Each formula comprised Moringa leaf flour (5, 6 and 7 grams each) combined with 30 grams of oatmeal powder, 40 grams of powdered formula, 10 grams of refined sugar, and 5 grams of banana flour.

Results: Based on the organoleptic test, Formula 3 (created with 5 grams of Moringa leaf flour) was discovered to be the best. The organoleptic evaluation panel consisted of 3 trained and 30 untrained participants, while the statistical results showed the parameters of colour, texture, and taste, have no significant effect on panellists' acceptance.

Conclusions: The flavour parameter has a significant effect on panellists' acceptance, with a p-value $<0.05$.
\end{abstract}

\section{Introduction}

Indonesia has the fifth highest prevalence of stunting in the entire world. Stunting is a state of malnutrition so that individuals will be short below the average growth chart. This condition is one of the contributors that cause an increase in early childhood death due to malnutrition which continues into the terminal phase. ${ }^{1}$ Furthermore, the 2018 Basic Health Research (Indonesian Ministry of Health) recorded a $30.8 \%$ national stunting prevalenc. ${ }^{2}$ However, stunting can be prevented by providing suitable complementary foods. Fresh Moringa leaves contain vitamin A, vitamin C, Vitamin B6, calcium, potassium, iron, and protein, and have a high nutritional content, compared to other foods. ${ }^{3-5}$ The leaves have a higher vitamin A content, $6.8 \mathrm{mg} / 100 \mathrm{~g}$, com- pared to the $1.8 \mathrm{mg} / 100 \mathrm{~g}$ contained in carrots, and a calcium content of $440 \mathrm{mg} / 100 \mathrm{~g}$, compared to the $6.49 \mathrm{mg} / 100 \mathrm{~g}$ present in milk. ${ }^{6-8}$ Meanwhile, Moringa leaves have a potassium content of $259 \mathrm{mg} / 100$ and banana has a counterpart of $88 \mathrm{mg} / 100 \mathrm{~g}$. Similarly, the leaves have quite a high protein content of $6.7 \mathrm{~g} / 100$ $\mathrm{g}$, compared to the $3.1 \mathrm{~g} / 100 \mathrm{~g}$ contained in yoghurt, as well as a vitamin C content of $220 \mathrm{mg} / 100 \mathrm{~g}$, compared to the $30 \mathrm{mg} / 100 \mathrm{~g}$ present in oranges. ${ }^{9}$ As a result, the leaves have been used for to combat malnutrition, especially in African countries. ${ }^{10,11}$ This study therefore aims to develop complementary foods for breastfeeding in the form of instant baby porridge, with the addition of Moringa leaf flour, to ensure complete nutritional content.

\section{Design and Methods}

This design of this study is based on the research and development model of Borg and Gall, ${ }^{12}$ consisting of 8 steps. These include, identifying and determining potential and problem, conducting preliminary studies and requirement analysis, establishing product specifications, developing initial product models, expert trials, field trials and product validation, product revision, suggestions for utilization, dissemination, and further product development. This study met the Brawijaya University's ethical clearance requirements and all the respondents consented to participation. In addition, this study has been approved by the health research ethics committee of the Faculty of Medicine, University of Brawijaya, with research ID 104/EC/KEPK-S1/03/2019.

The equipment used in this study include, oven, blender, 80 mesh sieves, bowls, and measuring scale. Meanwhile, the main ingredient used is Moringa leaf flour. The other ingredients for instant porridge include, oatmeal powder, powdered formula milk, fine granulated sugar, and banana flour, all obtained from minimarkets within Malang City. All formulations were carried out in accordance with the SNI 01-7111.4-2005 standard for instant complementary foods, and met the protein, fat, carbohydrate, as well as total calorie requirements. Also, complementary foods met the nutritional adequacy for infants aged 6-12 months. Table 1 shows the formula for complementary feeding (MP ASI).

Significance for public health

The problem of stunting in toddlers not only interferes with physical growth and development, but also with brain growth, thus, weakening the cognitive abilities of toddlers. Therefore, the condition must be resolved immediately. Furthermore, stunting affects productivity during adult stage, and is often prevented in public health by providing nutritious food intake for toddlers, through proper complementary feeding. Currently, the choice of complementary foods is solely commercial. Hence, there is a need for research and development with regard to the manufacture of complementary foods with practical, highly nutritious natural ingredients. 


\section{Moringa leaf flour production}

Green, fresh Moringa oleifera leaves were washed with water, de-stalked, spread on a dry container, then oven-dried for $120 \mathrm{~min}$ at $55^{\circ} \mathrm{C}$. Subsequently, the leaves were milled with a dry blender and sieved using an 80 mesh sieve, to remove any small uncrushed stalks present. ${ }^{13,14}$

The instant porridge mix was then created using a modification of the dry mixing method, as described by Yustiyani. ${ }^{15}$ This was performed by mixing all the ingredients, including Moringa leaf flour, oatmeal powder (Quaker Instant Oatmeal), powdered formula milk (Morinaga Chil Kid), and sugar, in a plastic bag, followed by manual shaking for $5 \mathrm{~min}$, until all the ingredients were completely blended. The Instant porridge mix was then served to the panel comprising of both trained and untrained sensory evaluators in a serving of 45 grams or 6 tablespoons for each.

The organoleptic test was performed by three trained panellists, 2 UM culinary art education lecturers and 1 UM Food Chemistry lecturer. Meanwhile, the untrained panellists comprised 30 mothers of babies or toddlers in Batu City. The test was designed to evaluate 4 parameters, colour, flavour, texture, and taste, using 6 hedonic scales, Very much like, Very like, Like, Rather like, Neutral, and Dislike. Also, the product's nutritional

Table 1. Instant porridge formula.

\begin{tabular}{|c|c|c|c|}
\hline \multirow[t]{2}{*}{ Ingredients } & \multicolumn{3}{|c|}{ Instant baby porridge formula $(\mathrm{g})$} \\
\hline & F1 & F2 & F3 \\
\hline Moringa leaf flour & 7 & 6 & 5 \\
\hline Oatmeal powder & 30 & 30 & 30 \\
\hline Powdered formula & 40 & 40 & 40 \\
\hline Fine granulated sugar & 10 & 10 & 10 \\
\hline Banana flour & 5 & 5 & 5 \\
\hline
\end{tabular}

content was determined based on the overall calculation of nutritional content for the ingredients, according to Winarno reference ${ }^{16}$ for Moringa leaf flour, as well as the 2017 Indonesian Food Composition Table (TKPI), with the linear nutrition survey program. Subsequently, all quantitative data obtained were tabulated and statistically analysed with the Friedman Test to investigate the differences between the three formulas.

\section{Results and Discussions}

\section{Nutritional contents}

Table 2 shows the product's nutritional content. The energy value indicates the difference in the concentration of Moringa leaf influences the results obtained. Furthermore, the lowest energy value, $196 \mathrm{kcal}$, was attained in third formula, with a concentration of 5 grams of Moringa leaf flour, while the highest, $200 \mathrm{kcal}$, was obtained in the first, with a concentration of 7 grams of Moringa leaf flour. The energy value is as a result of the carbohydrates, fats and proteins in the porridge. This corresponds with the statement by Hardinsyah, ${ }^{17}$ stating energy is only obtainable from carbohydrates, proteins and fats contained in food and stored in the human body, to be utilized for growth and development.

The Moringa leaf powder instant porridge mix with the lowest protein content of 7 grams per serving was the third formula (F3), while the highest was the first formula (F1), with 8 grams per serving. This shows an increase in Moringa leaf flour content is likely to cause an increase in the protein content of the porridge, and is in accordance with the report by Farooq ${ }^{18}$ stating Moringa leaf flour has a very high protein content, of 27.1 grams/100 grams. Therefore, the flour meets the protein standard of instant complementary powder in SNI 01-7111.1-2005, ranging from 8-22

Table 2. Product nutritional content.

\begin{tabular}{|c|c|c|c|c|}
\hline $\begin{array}{l}\text { Parameter } \\
\text { Serving size }\end{array}$ & $\begin{array}{c}\text { F1 } \\
6 \text { tablespoons }=45 \text { grams }\end{array}$ & $\begin{array}{c}\text { F2 } \\
6 \text { tablespoons }=45 \text { grams }\end{array}$ & $\begin{array}{c}\text { F3 } \\
6 \text { tablespoons }=45 \text { grams }\end{array}$ & $\begin{array}{c}\text { Commercial porridge } \\
6 \text { tablespoons }=40 \text { grams }\end{array}$ \\
\hline Number of servings per package & 2 & 2 & 2 & 3 \\
\hline \multicolumn{5}{|l|}{ Amount per serving } \\
\hline Total energy & $200 \mathrm{kcal}$ & $198 \mathrm{kcal}$ & $196 \mathrm{kcal}$ & $160 \mathrm{kcal}$ \\
\hline Protein (g) & 8 & 8 & 7 & 4 \\
\hline Fat (g) & 7 & 7 & 7 & 2.5 \\
\hline Carbohydrate (g) & 26 & 25 & 24 & 31 \\
\hline Dietary fibre (g) & 1 & 1 & 1 & 3 \\
\hline Potassium (mg) & 390 & 384 & 378 & 100 \\
\hline$\%$ RDA & $\%$ RDA & $\%$ RDA & $\%$ RDA & \\
\hline Protein & 45 & 44 & 43 & 20 \\
\hline Vitamin A & 45 & 44 & 44 & 40 \\
\hline Vitamin C & 37 & 33 & 29 & 50 \\
\hline Vitamin B1 & 60 & 56 & 56 & 30 \\
\hline Vitamin B2 & 68 & 68 & 53 & 30 \\
\hline Calcium & 104 & 100 & 96 & 35 \\
\hline Phosphor & 83 & 82 & 82 & 35 \\
\hline Iron & 26 & 26 & 24 & 50 \\
\hline Zinc & 28 & 28 & 28 & 25 \\
\hline
\end{tabular}

Source: Indonesian Food Composition Table, ${ }^{2}$ and Winarno. ${ }^{9}$ 
grams/100 grams.

According to Table 2, the difference in the concentration of Moringa leaf flour has no effect on the product's fat content, as the three formulas all contained 7 grams of fat, in each serving. This is in accordance with the fat content requirement for instant powdered complementary food, 6-15 grams/100 grams, as stated in SNI 01-7111.1-2005.

In addition, the carbohydrate content of the Moringa leaf powder was discovered to be influenced by the Moringa leaf flour content. The lowest carbohydrate content, 24 grams, was obtained in was in the third formula, while the highest, 26 grams, was observed in the first formula. Carbohydrates are the main source of calories and play a role in determining the properties of food, including colour, taste, and texture. ${ }^{16}$ Also, these results are in accordance with the carbohydrate standards of instant powdered complementary foods, not more than 7.5 grams/100 kcal or 30 grams/100 grams, as stated in SNI 01-7111.1-2005. The difference in the concentration of Moringa leaf flour was also found to have no effect on fibre content, as all three formulas had a fibre content of 1 gram in each serving. This is in accordance with the instant powdered complementary food standard for fibre, not more than 5 grams/100 grams, as stated by SNI 01-7111.1-2005. Table 2 also shows the Moringa leaf instant porridge mix fulfils up to $45 \%$ of the vitamin A, $37 \%$ of the vitamin C, $60 \%$ of the vitamin B1, $68 \%$ of the vitamin B2, $26 \%$ of the iron, $28 \%$ of the zinc, $83 \%$ of the phosphorus, and $100 \%$ of the calcium recommended dietary allowance (RDA) per serving, for infants aged 6-12 months. The last two minerals are very crucial in preventing stunting.

Calcium is an essential micronutrient for linear growth during early. ${ }^{19}$ Furthermore, $70 \%$ of bone weight consists of calcium phosphate crystals, and this shows the mineral's significance for optimal bone growth. ${ }^{20}$ Calcium deficiency has detrimental effects on immunity and bone health, and is mainly caused by inadequate intake and or suboptimal absorption. Therefore, inadequate calcium consumption in toddlers affects the basic structure of the bones, resulting in stunting or other growth impairments. ${ }^{21,22}$

\section{Trained panellists' organoleptic test}

Table 3 shows the organoleptic test performed by trained panellists. This was the first step to obtain criticism and suggestions regarding the development of instant baby porridge with Moringa leaf flour. In this step, 3 samples of instant porridge were made with a difference in the concentration of 2 grams of moringa leaf flour in each formula. The first, second and third formulas had concentrations of 10, 8 and 6 grams of Moringa leaf flour, respectively. The trained panellists, culinary art education lecturers at the Faculty of Engineering, State University of Malang, evaluated the results of the development, through an organoleptic test questionnaire based on 4 assessment parameters: colour, flavour, texture, and taste, using 6 levels of preference, very much like, very like, really like, like, rather like, neutral, and dislike. According to the organoleptic evaluation, the third instant porridge formula was most preferred by the panellists. Meanwhile, the highest average value for the colour, flavour, texture and parameters (Formula 3)

Table 3. Trained panellist organoleptic test results.

\begin{tabular}{lccc} 
Parameter & F1 & F2 & F3 \\
Colour & 3 & 3.33 & 4.33 \\
Flavour & 1.33 & 2 & 3.33 \\
\hline Texture & 3.33 & 3.66 & 4.33 \\
Taste & 1 & 1.33 & 3.33 \\
\hline
\end{tabular}

were $4.33,3.33,4.33$, and 3.33 , respectively. These values are all within the range of like. Subsequently, data from the nutritional evaluation of the instant porridge developed with Moringa leaf powder generated some suggestions. These include the need to perform pre-treatment of the leaves to reduce the smell's intensity, and to reduce the levels of Moringa leaf flour by formulating the porridges with a difference of 1 gram of leaf flour.

The development's results were also justified by a lecturer in the Department of Chemistry, Faculty of Mathematics and Natural Sciences, State University of Malang, through an organoleptic test questionnaire based on 4 assessment parameters, colour, flavour, texture, and taste, using 6 scale of preference levels, very much like, very like, really like, rather like, neutral, and dislike. The data from this evaluation generated the same suggestion as the other trained panellists.

\section{Untrained panellists' organoleptic test}

Figure 1 shows the results of colour assessment. Based on this evaluation increase in moringa leaf flour content was discovered to produce a darker green colour in the product, while a reduction in flour content was found to cause a light or even pale coloration. In addition to raw materials, the production process is also regarded to affect the colour of instant baby porridge. ${ }^{23}$ The colour assessment showed the panellists tend to prefer light green, as increase in Moringa leaf flour content lead to a decrease in the preference value for colour. Subsequently, the differences between the panellists' preference for F1, F2, and F3 were tested using the Friedman test. The results had a p-value of $0.856(>0.05)$, indicating the three formulations have no significant difference in panellist acceptance. Meanwhile, Figure 2 shows the result of flavour assessments. Based on this evaluation, the third formulation with a concentra-

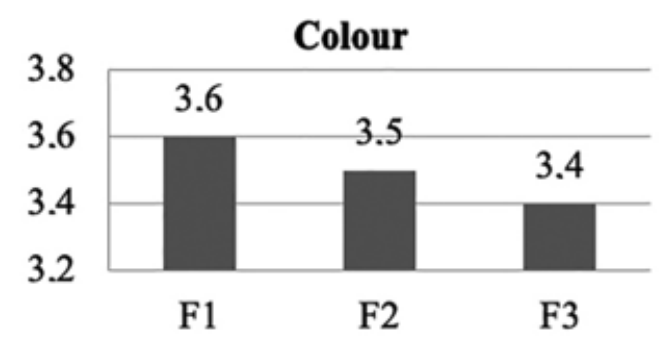

Figure 1. Organoleptic test for colour parameters

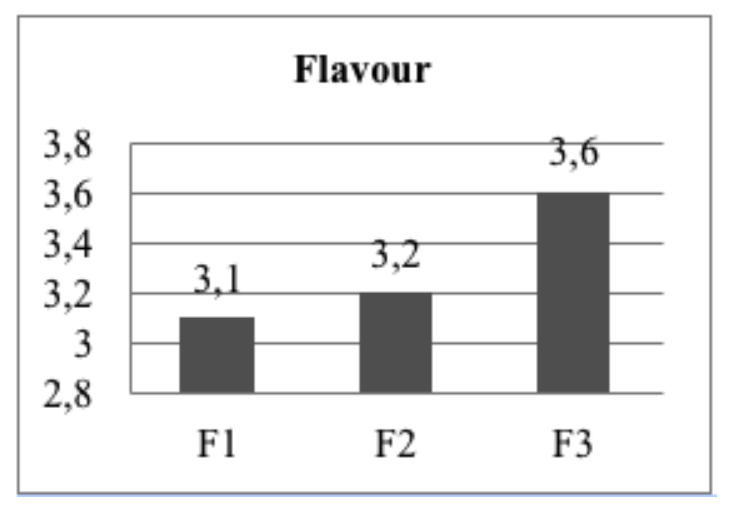

Figure 2. Organoleptic Test for Flavour Parameters. 
tion of 5 grams of Moringa leaf flour was most preferred formula for the 30 untrained panellists, with an average value of 3.6 or within the range of likes. An increase in Moringa leaf flour content was found to produce an unpleasant aroma. Hence, panellists preferred the formula with less leaf flour. Moringa leaves have a distinctly unpleasant aroma due to the presence of lipoxidase enzymes. ${ }^{24}$ Subsequently, the differences between the panellists' preference for F1, F2, and F3 were tested using the Friedman test. This resulted in a p-value of $0.034(<0.05)$, indicating the three formulations had significant differences in panellist acceptance. Figure 3 shows the results of texture evaluation. Instant porridge with Moringa leaf flour has a creamy, not too liquid texture, and this is thought to be as a result of the raw materials used. In addition, the process of sieving instant baby porridge mix helped to prevent the occurrence of gritty texture. ${ }^{25}$ The differences between the panellists' preference for F1, F2, and F3 were then tested using the Friedman test. This resulted in a p-value of $0.2(>0.05)$, indicating the three formulations had no significant difference in panellist acceptance.

Figure 4 shows the results of taste assessment. The taste of the third formulation was found to be most preferred by the 30 panellists, with an average value of 3.6 or within the range of really like and like. This is because an increase in Moringa leaf flour will increase the bitter taste as Moringa leaves contain alkaloid compounds. ${ }^{26}$ Therefore, the panellists preferred the porridge with the least Moringa leaf flour content. The differences between the panellists' preference for F1, F2, and F3 were tested using the Friedman test. This resulted in a p-value of $0.074(>0.05)$, indicating the three formulations have no significant difference in panellist acceptance.

Moringa leaf flour instant porridge has a higher nutritional value compared to commercial instant porridge. A single serving of

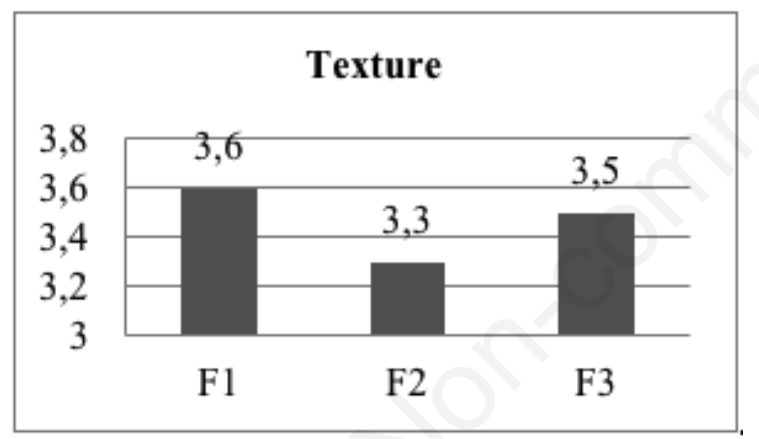

Figure 3. Organoleptic Test for Texture Parameters.

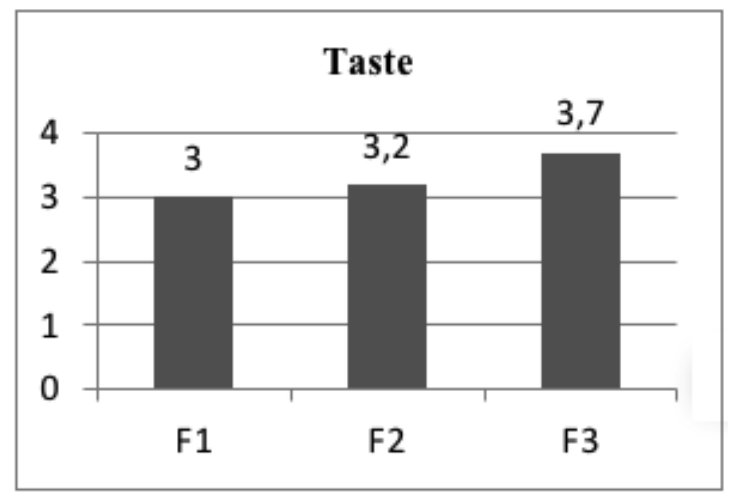

Figure 4. Organoleptic Test for Taste Parameters. the Moringa leaf flour instant porridge has twice the protein content as the commercial counterpart, as well as higher vitamins and mineral, content, with the exception of vitamin $\mathrm{C}$, as a result of the drying process. Long drying time causes a decrease in the vitamin levels of the ingredients. According to Mukaromah, ${ }^{27}$ reduction in vitamin $\mathrm{C}$ is due to high temperature treatment for a long time. In this study, drying was carried out at a temperature of $55^{\circ} \mathrm{C}$ for 120 min, to obtain the highest antioxidant activity of Moringa leaves, as described by Ferreira. ${ }^{28}$

\section{Conclusions}

The resulting product's nutritional value of baby porridge is in accordance with SNI 01-7111.1-2005, and it is prepared for consumption by simply brewing with hot water. Meanwhile, organoleptic evaluations showed colour, texture, and taste, had no significant influence on panellist acceptance, but flavour had a significant effect, with a p-value $>0.05$. Furthermore, the results showed formula with the best Moringa leaf flour content, was F3 (5 grams of leaf flour), with an energy of $196 \mathrm{kcal} / \mathrm{serving}$.

Correspondence: Septa Katmawanti, Department of Public Health, Faculty of Sport Science, Universitas Negeri Malang, J1. Semarang No.5, Sumbersari, Kec. Lowokwaru, Kota Malang, Jawa Timur 65145 , Indonesia.

Tel. +62.341.3301130 - Fax: +62.341.551921.

E-mail: septakatma.fik@um.ac.id

Key words: Instant porridge; moringa leaf flour; stunting.

Acknowledgment: The authors are grateful to the Faculty of Sport Science, Universitas Negeri Malang, Malang, Indonesia, for providing kind support and encouragements during this study.

Contribution: All authors contributed equally to this article. FM conducted this study; SK, SS served as supervisors and reviewed the final document.

Conflict of interest: The authors declare no potential conflict of interest.

Funding: This study was financially supported by Faculty of Sport Science, Universitas Negeri, Malang, Indonesia.

Ethics approval: This study has been approved by Health Research Ethics Committee of Faculty of Medicine with ID research, University of Brawijaya, Indonesia (ID 104/EC/KEPK-S1/03/2019).

Conference presentation: Part of this study was presented at the $1^{\text {st }}$ International Nursing and Health Sciences Symposium, November $13^{\text {th }}$ to $15^{\text {th }} 2020$, Brawijaya University, Malang, Indonesia.

Received for publication: 14 January 2021.

Accepted for publication: 15 March 2021.

oCopyright: the Author(s), 2021

Licensee PAGEPress, Italy

Journal of Public Health Research 2021;10:2233

doi:10.4081/jphr.2021.2233

This work is licensed under a Creative Commons Attribution NonCommercial 4.0 License (CC BY-NC 4.0). 


\section{References}

1. Susanto H, Hernowati TE, Indra MR. Efficacy of moringaoleifera leaf powder as nutrigenomic therapy: A preliminary study of madura islands variety. Nephrourol Mon 2014;6:e17945.

2. Ministry of Health of the Republic of Indonesia. [Pedoman Metode Melengkapi Nilai Gizi Bahan Makanan Pada Tabel Komposisi Pangan Indonesia (Method guidelines for complementing the nutritional value of food ingredients in the Indonesian food composition table)].[Book in Indonesian]. Jakarta: Ministry of Health, Republic of Indonesia; 2017.

3. Sedgh G, Guillermo Herrera M, Nestel P, et al. Dietary vitamin A intake and nondietary factors are associated with reversal of stunting in children. J Nutr 2000;130:2520-6.

4. Fahey J. Moringa oleifera: A review of the medical evidence for its nutritional, therapeutic, and prophylactic properties. Trees Life J 2005; 1:5.

5. Hsu HW, Vavak DL, Satterlee LD. et al. A Multienzyme technique for estimating protein digestibility. J Food Sci 2006;42:1269-73.

6. Ma Z, Ahmad J, Zhang H, et al. Evaluation of phytochemical and medicinal properties of moringa (Moringa oleifera) as a potential functional food. South African J Bot 2020;129:40-6.

7. Kasolo JN, Bimenya GS, Ojok L, et al. Toxicity evaluation of Moringa oleifera leaves aqueous and ethanol extracts in Swiss Albino rats. Int J Med Plant Res 2012;1:75-81.

8. Tirhas MG, Geremew B, Sirawdink FF, et al. Nutritional quality and acceptability of sweet potato-soybean-moringa composite porridge, nutrition and food science. Nutr Food Sci 2015;45:845-58.

9. Winarno. [Tanaman Kelor (Moringa oleifera) Nilai Gizi, Manfaat, dan Potensi Usaha (Moringa oleifera nutritional value, benefits, and business potential)].[Book in Indonesian]. Jakarta: Gramedia Pustaka Utama; 2018.

10. Putra AIYD, Setiawan NBW, Sanjiwani MID, et al. Nutrigenomic and biomolecular aspect of Moringa oleifera leaf powder as supplementation for stunting children. J Trop Biodivers Biotechnol 2021;6:60113.

11. Mushaphi LF, Motadi SA, Mbhatsani HV, et al. Pregnant women's dietary practices in relation to anthropometric status of infants aged 0-6 weeks in Vhembe district, Limpopo Province Mushaphi. J Nutr Food Sci 2015;5:6.

12. Borg WR, Gall M. Educational Research: An Introduction, Fifth Edition. London: CRC Press Taylor dan Francis Group; 1983.

13. Agunbiade OJ, Famutimi OG, Kadiri FA, et al. Studies on peroxidase from Moringa oleifera Lam leaves. Heliyon 2021;7:e06032.

14. Shiriki D, Igyor MA, Gernah DI. Nutritional evaluation of complementary food formulations from maize, soybean and peanut fortified with Moringa oleifera leaf powder. Food Nutr
Sci 2015;6:494-500.

15. Yustiyani Y, Setiawan B. [Formulasi Bubur Instan Menggunakan Komposit Tepung Kacang Merah Dan Pati Ganyong Sebagai Makanan Sapihan (Instant porridge formulation using red bean flour composite and canna starch as weaning food)].[Article in Indonesian]. J Gizi dan Pangan 2014;8:95.

16. Winarno. [Kimia Pangan dan Gizi (Food chemistry and nutrition)].[Book in Indonesian]. Jakarta: Gramedia Pustaka Utama; 2004.

17. Hardinsyah, Riyadi H, Napitupulu V. [Kecukupan energi, protein, lemak dan karbohidrat (Adequacy of energy, protein, fat and carbohydrates)].[In Indonesian]. Bogor: Community Nutrition, FEMA IPB and the Department of Nutrition, FK UI, Bogor and Jakarta; 2012.

18. Farooq F, Rai M, Tiwari A, et al. Moringa oleifera as an alternative fodder for dairy cows in Nicaragua. J Med Plants Res 2012;6:4368-74.

19. Gupta S, Jain R, Kachhwaha S KS. Nutritional and medicinal applications of Moringa oleifera Lam.-Review of current status and future possibilities. J Herb Med 2018;11:1-11.

20. Netshiheni KR, Mashau M, Jideani AI. Nutritional and sensory properties of instant maize porridge fortified with Moringa oleifera leaves and termite (Macrotermes falciger) powders. Nutr Food Sci 2019;49:654-67.

21. Khatun S, Ashraduzzaman, Karim R, et al. Purification and characterization of peroxidase from moringa oleifera 1. leaves. BioResources 2012;7:3237-51.

22. Fatima T, Sajid MS, Jawad-ul-Hassan M, et al. Phytomedicinal value of Moringa oleifera with special reference to antiparasitics. Pakistan J Agric Sci 2014;51:251-62.

23. Popoola OJ, Obembe O. Local knowledge, use pattern and geographical distribution of Moringa oleifera Lam. (Moringaceae) in Nigeria. Encycl Toxicol 2013;150:682-91.

24. Leone A, Spada A, Battezzati A, et al. Cultivation, genetic, ethnopharmacology, phytochemistry and pharmacology of Moringa oleifera leaves: An overview. Int J Mol Sci 2015;16:12791-835.

25. Moyo B, Masika PJ, Hugo A, et al. Nutritional characterization of Moringa (Moringa oleifera Lam.) leaves. African J Biotechnol 2011;10:12925-33.

26. Onyekwelu O, Ekechi A. In vitro and in vivo evaluation of antioxidant properties of Moringa Oleifera ethanolic leaves extract and effect on serum lipid indices in rat. Maced J Med Sci 2012;5:397-403.

27. Goyal BR, Agrawal BB, Goyal RK, et al. Phyto-pharmacology of Moringa oleifera Lam. - An overview. Nat Prod Radiance 2007;6:347-53.

28. Ferreira PPM, Farias DF, Oliveira JTDA, et al. Moringa oleifera: bioactive compounds and nutritional potential Moringa oleifera : compostos bioativos e potencialidade nutricional. Rev Nutr 2008;21:431-7. 